\section{Alkali Inspectorate still at first base}

Eleanor Lawrence

Her Majesty's Alkali and Clean Air Inspectorate comes under strong criticism in a recent report for its attitude to the problems of pollution control which, says the report, is now out of date and often ineffective. (The Alkali Inspectorate, Social Audit, 9 Poland Street, London WIV 3DG, £1).

The report, prepared by Maurice Fraenkel for Social Audit, criticises the inspectorate for not publishing the detailed data it collects and for general secrecy and non-cooperation towards members of the public and local authorities who make complaints against specific works. Also, says the report, it seems unwilling to put the maximum pressure on factories who do not comply even with its standards.

These specific criticisms stem from the way the inspectorate itself sees its role in controlling industrial pollution. In the words of the present Chief Alkali Inspector, Mr F. E. Ireland, the first Chief Inspector, Dr Angus Smith in 1863 "set the policy pattern of the inspectorate which has been followed ever since". This policy involved a sympathetic approach towards the manufacturers which included technical help towards solving their problems which was very welcome and did result in the early days of the inspectorate in a tremendous reduction of pollution. But, says the report, times have changed and this attitude may not be quite so effective nowadays and is in fact blocking the way to a more effective control of pollution.

"We like to help industry", $\mathrm{Mr}$ Ireland told the author of the report, "when we visit a works they are actually glad to see us." But from the outside, local authorities and members of the general public have made many complaints that the standards that the inspectorate itself lays down are often not being followed by the factories and that the inspectorate will allow works more than ample time to put their house in order even when this results in serious nuisance to local residents.

Local authorities which, through their own Public Health Inspectors, control pollution from all the factories and processes that are not registered under the Alkali Act, are one of the main critics of the Alkali Inspectorate. Some of the larger authorities have tried to break into the mutual admiration society obtaining between the inspectorate and the industries they monitor by suggesting that they should take over the inspectorate's duties, but this suggestion has been repulsed both by the inspectorate and by the industries themselves, who are seemingly unwilling to leave the inspectorate's protection.

Many of the complaints about inefficiency on the part of the inspectorate can be traced to its staffing which is described in the report as totally inadequate. Thirty-five inspectors monitor the 2,000 -odd works registered under the Alkali Act and in these circumstances even the inspectorate admits it is unable to carry out the job as well as it would like.

The report concludes that despite its proud record and the undoubted technical expertise and determination of its staff, the Alkali Inspectorate is particularly ill-suited to the role now expected of it. It suggests that the simplest solution to the problem might be to transfer the responsibility for control of registered works to the local authorities, which nowadays have the technical skills needed to deal with this sort of work.

If the Alkali Inspectorate is to continue as an enforcement agency, then it needs more staff and more frequent inspections; but most of all, says $\mathrm{Mr}$ Fraenkel, it must be made accountable and all pollution data other than genuine industrial secrets must be published in a readily available form. The inspectorate's defence of its policy of non-publication is that the public does not understand pollution data.

\section{Azbel's visa}

WE have just received news that Professor David Azbel, one of the three Jewish intellectuals who went on hunger strike "taking a step befitting political prisoners" earlier this year (Nature, 248, 2-3 (1974) ) has received a visa permitting him to leave the Soviet Union. No visas have as yet been granted to his fellow strikers, Vitalii Rubin and Vladimir Galatskii.

\section{Happy birthday, Soviet style \\ Vera Rich}

As readers will be aware by now, the 250th Anniversary Meeting of the Soviet Academy of Sciences has been postponed. A brief note in the Pravda of May 6, 1974 (which appeared on page 2 , the page devoted to Party and political news) announced:

"The Acaderny of Sciences of the USSR with the approval of the Central Committee of the Communist Party of the Soviet Union has resolved to postpone the meeting devoted to the 250 th anniversary of its foundation, from May, 1974, until a later date. During this time, celebratory (anniversary) meetings of the Academies of Science in the Union Republics will be held with the participation of Soviet society. Meetings devoted to the anniversary of the Academy of Sciences of the USSR, and to problems of the better implementation of scientific achievements in practice, will also be held in scientific institutions and establishments. It is intended that scientists will speak at industrial enterprises, collective farms and state farms with the aim of popularising scientific knowledge among the workers. The Academy of Sciences will complete its preparations and the publication of fundamental scientific works in honour of the anniversary, and will organise thematic exhibitions under the slogan, "The Achievements of Science are for the National Economy'."

In these brief words, the preparations and expeztations for a grand international celebration are "postponed'-a word which may be taken in its literal sense, but which under the Stalin bureaucracy was a frequent euphemism for 'scrapped'

There is of course a certain suggestion of unpreparedness here-that although the resolutions to celebrate the anniversary were published last autumn, the Academy is still in a state of unreadiness. In spite of the Soviet predilection for the fulfilment of norms ahead of schedule, such lack of preparedness for conferences has been known to occur.

Even if there has been some tardiness in preparation, however, this is not the full story, particularly as the date of the 'foundation' of the Academy can be interpreted in more than one way. What it was intended to celebrate this year was the issuing of a decree by Peter I ("the Great") establishing the Academy, on January 28, 1724. Having begotten the Academy, however, Peter died and the inaugural meeting took place nearly two years later, on December 27, 1725, in the presence of Peter's widow and successor Catherine I. On at least one occasion, the 1725 date has been celebrated as the anniversary; in 1945 a 220 th jubilee celebration was held and. although under war conditions a 1944 celebration would have been impossible, there was nothing in the official publications about the occasion to suggest that this was in any sense a postponement.

Looking closer at the announcement, however, it is not merely a postponement; it is a change of aim and intention. Instead of a grand international gathering (which has been 'postponed'), there are concrete plans for lectures on the grass roots of Soviet society and a stress on scientific utilitarianism.

But would it have been an international meeting at all? Would the leading scientists of the world really 